\title{
Platelet Index in Patients with Confirmed Coronavirus Disease 2019 Cases
}

\author{
Haerani Harun ${ }^{1}$, Christin Rony Nayoan ${ }^{2 *}$, Ipfi White ${ }^{3}$, Nur Syamsi ${ }^{4}$, Andi Alfia Mutmainnah Tanra ${ }^{4}$, Sarifuddin Sarifuddin ${ }^{5}$
}

${ }^{1}$ Department of Clinical Pathology, Faculty of Medicine, Tadulako University, Palu, Indonesia; ${ }^{2}$ Department of Otorhinolaryngology, Faculty of Medicine, Tadulako University, Palu, Indonesia; ${ }^{3}$ Department of Obstetrics-Gynecology, Faculty of Medicine, Tadulako University, Palu, Indonesia; ${ }^{4}$ Department of Pharmacology, Faculty of Medicine, Tadulako University, Palu, Indonesia; ${ }^{5}$ Department of Anatomy, Faculty of Medicine, Tadulako University, Palu, Indonesia

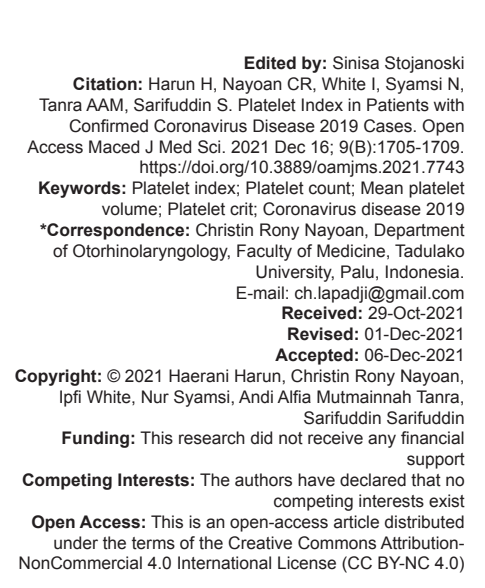

\begin{abstract}
BACKGROUND: Changes found on hematological examination are a helpful modality for assessing coronavirus disease 2019 (COVID-19). In addition, platelet index is a parameter that can help in assessing the COVID-19 disease prognosis.

AIM: Objective of the study is to determine the difference in platelet index in nucleid acid amplification test (NAAT) confirmed COVID-19 patients, suspected COVID-19 with negative NAAT results, and non-COVID-19 controls.

METHODS: This is an analytical observational study with 96 subjects; 48 subjects with confirmed COVID-19, 23 subjects suspected COVID-19 with negative NAAT results, and 24 non-COVID-19 control subjects. First, NAAT examination was carried out using the GeneXpert tool with the target genes of the $E$ and N2 genes. Then, the platele index was compared between the three groups by the Kruskal-Wallis test.

RESULTS: There was no significant difference in the number of platelet (PLT), mean PLT volume (MPV), and PLT crit (PCT) between the three groups with $p=0.732,0.741$ and 0.483 , respectively. In general, the number of PLT, MPV, and PCT in the three groups was within the normal reference value.

CONCLUSIONS: There were no significant differences observed in the number of PLT, MPV, and PCT between COVID-19 patients with positive NAAT, COVID-19 suspects with negative NAAT, and non-COVID-19 controls. Therefore, detecting the severe acute respiratory syndrome coronavirus 2 virus by NAAT examination in COVID-19 patients has not altered the PLT index changes.
\end{abstract}

\section{Introduction}

Thecoronavirusinfectiousdisease(Coronavirus disease 2019 [COVID-19]) or severe acute respiratory syndrome coronavirus 2 (SARS-CoV-2) pandemic that began in December 2019 in Wuhan, China, was caused by the Coronavirus 2 and has infected millions of people worldwide. Most COVID-19 patients have mild to moderate symptoms and will recover over time. However, around $15-32 \%$ of COVID-19 patients experienced severe clinical manifestation symptoms that led to severe acute respiratory syndrome, critical conditions and even death [1], [2], [3].

Changes in the hematological examination are modalities that can help to assess COVID-19 infection and can help clinicians assess the degree and prognosis of the disease in COVID-19 patients [2]. Hematological examinations are easy to administer, readily available in all hospitals, and relatively inexpensive to provide flexibility for routine hematological examinations for COVID-19 patients who require rapid laboratory results [2], [4].
Platelets (PLTs) play an important role in hemostasis and thrombosis, but the understanding of PLTs is becoming more widespread today in human biological processes, including inflammation, wound healing, and angiogenesis. Previously, a PLT-mediated immune response has been reported in viral infections. However, recent reports have shown changes in gene expression profiles and functional responses in patients with COVID-19 infection [4], [5], [6]. PLT parameters include the PLT type or PLT count, mean PLT volume (MPV), and PLT crit (PCT). However, research on the parameters of the PLT profile in infection conditions, especially COVID-19 infection, is rarely discussed. Therefore, we examined the parameters of the PLT profile in patients with COVID-19.

\section{Methods}

This study is an observational analytical study with a cross-sectional design. This study uses 
secondary data from medical records of hospitalized COVID-19 patients at Anutapura Hospital, which was conducted from January 2020 until. The study population was patients at Anutapura Hospital during the study period. The samples of this study were COVID-19 patients, both those with confirmed cases and those who were not confirmed, and patients who had medical check-ups. The minimum sample in this study is 24 samples for each group, so a total of 72 samples was required. Inclusion criteria include patients with confirmed COVID-19 by internal medicine specialists or pulmonary specialists based on assessment, physical examination, supporting examinations, and had performed traditional Chinese medicine and routine blood laboratory tests. The exclusion criteria were patients with incomplete data and had hematological or hemostatic disease. This study was conducted with the permission and knowledge of the patient through an informed consent sheet and was declared to meet the ethical requirements to be conducted by the Health Research Ethics Committee.

The study samples which met the inclusion criteria were divided into three groups; the positive polymerase chain reaction (PCR) confirmed group, the COVID-19 suspect group with negative PCR, and the healthy subjects. Then, the laboratory and the PCR examination results were collected. In addition, data collection was also gathered from the examination results of healthy subjects. The data obtained were then tabulated and analyzed according to the study objectives.

The Kolmogorov-Smirnov test was used to assess normality in the data distribution. The PLT, MPV, and PCT values were then compared with the One-way analysis of variance test and the Kruskal Wallis as an alternative test. If there is a significant difference, then it is continued with the post hoc test.

\section{Results}

A total of 96 subjects was included in this study; 48 subjects with confirmed COVID-19 cases, 23 suspected COVID-19 subjects with negative nucleid acid amplification test (NAAT) results, and 24 non-COVID-19 control subjects. Research data shows that the age of patients with confirmed and unconfirmed COVID-19 cases is mostly young adults to the elderly, while non-COVID-19 controls were majority young adults who did medical check-ups before the spread of COVID-19 (Table 1).

In this study, the age range of patients with confirmed COVID-19 cases was not significantly different from patients with suspect COVID-19 cases with negative NAAT results. Meanwhile, most of the
Table 1: Sample characteristics

\begin{tabular}{|c|c|c|c|}
\hline Parameter & $\begin{array}{l}\text { Confirmed COVID-19 } \\
\text { cases }(n=48)\end{array}$ & $\begin{array}{l}\text { Suspect COVID-19 } \\
\text { cases }(n=23)\end{array}$ & $\begin{array}{l}\text { Control } \\
(n=24)\end{array}$ \\
\hline \multicolumn{4}{|l|}{ Age } \\
\hline Median (min-max) & $48(20-77)$ & $46(17-74)$ & $25(19-34)$ \\
\hline \multicolumn{4}{|l|}{$\operatorname{Sex}(n, \%)$} \\
\hline Male & $24(50)$ & $12(52.2)$ & $19(76)$ \\
\hline Female & $24(50)$ & $11(47.8)$ & $6(24)$ \\
\hline \multicolumn{4}{|l|}{$\operatorname{PLT}\left(10^{3} / \mu \mathrm{L}\right)$} \\
\hline Median (min-max) & $246(47-685)$ & $274(13-468)$ & $261(170-403)$ \\
\hline \multicolumn{4}{|l|}{$\operatorname{MPV}\left(\mu \mathrm{m}^{3}\right)$} \\
\hline Median (min-max) & $7.9(4.7-10.4)$ & $7.7(6.5-9.7)$ & $7.8(6.9-9.9)$ \\
\hline \multicolumn{4}{|l|}{ РCT (\%) } \\
\hline Median (min-max) & $0.198(0.05-0.47)$ & $0.221(0.01-0.55)$ & $0.210(0.16-0.24)$ \\
\hline
\end{tabular}

control group was categorized as young adults. The median value of the PLT count in all study groups was in the normal value $\left(150-450 \times 10^{3} / \mu \mathrm{L}\right)$. A total of $8(16 \%)$ subjects with thrombocytopenia and $3(0.06 \%)$ subjects with thrombocytosis from a total of 48 subjects were found in the confirmed COVID-19 cases group. Thus, PLT counts that exceed the reference value have a relatively low percentage-10\% of confirmed COVID-19 cases. From a total of 23 subjects in the suspected COVID-19 group, there were $4(17 \%)$ subjects with thrombocytopenia and 1 (0.04\%) subject with thrombocytosis. Meanwhile, in the control group, all the PLT counts were within normal reference values.

The results of the test of difference on the PLT index between COVID-19 patients with positive NAAT, COVID-19 suspects with negative NAAT, and non-COVID-19 controls did not show any significant differences with $p>0.05$, both in the PLT count, MPV, and PCT value (Table 2).

Table 2: Comparison of platelet index in confirmed COVID-19 patients, suspects COVID-19 cases, and controls

\begin{tabular}{|c|c|c|c|c|}
\hline Platelet index & $\begin{array}{l}\text { Confirmed } \\
\text { CoVID-19 cases } \\
n=48)\end{array}$ & $\begin{array}{l}\text { Suspect } \\
\text { COVID-19 } \\
(\mathrm{n}=23)\end{array}$ & $\begin{array}{l}\text { Control } \\
(n=24)\end{array}$ & p-value ${ }^{*}$ \\
\hline $\operatorname{PLT}\left(10^{3} / \mu \mathrm{L}\right)$ & & & & \\
\hline $\begin{array}{l}\text { Median (min-max) } \\
\text { MPV }\left(\mu^{3}\right)^{3}\end{array}$ & $246(47-685)$ & $250(13-468)$ & $261(170-403)$ & 0.732 \\
\hline Median (min-max) & $7.9(4.7-10.4)$ & $7.8(6.5-9.7)$ & $7.8(6.9-9.9)$ & 0.741 \\
\hline Median (min-max) & $0.198(0.05-0.47)$ & $0.199(0.01-0.55)$ & $\begin{array}{l}0.210 \\
(0.16-0.24)\end{array}$ & 0.483 \\
\hline
\end{tabular}

\section{Discussion}

The pathophysiology of COVID-19 is not yet clear, regardless, there have been many discoveries related to the transmission and presentation of SARS-CoV-2. This virus enters through the respiratory system where there is high expression of main receptor for viral entry - angiotensin converting enzyme 2 [7], [8]. The virus performs local replication and propagation along with infection from ciliated cells in the airways. This phase lasts for several days, and the immune response initiated in this phase is limited. Although 
the viral load during this phase is low, the individual is highly contagious, and the virus can be detected by nasal swab examination [7].

Viral infections can induce abnormal changes in hematological parameters, including cell counts-anemia, neutropenia, and thrombocytopenia. This condition is thought to be due to an autoimmune response and suppression of bone marrow progenitor cells. Several theories have been proposed to explain the effect of viral infection on PLT count, but factors leading to thrombocytopenia in viral infections are not fully understood [9]. Thrombocytopenia is a common finding in viral infections, and proposed mechanisms include PLT destruction mediated by PLT-associated immunoglobulin G or PLT-leukocyte aggregation, PLT sequestration by macrophages, PLT sequestration in the spleen, impaired thrombopoiesis, and direct effects of the virus on PLTs [10].

Research on PLTs and their role in the course of COVID-19 has been extensively studied [6], [12], [13], [14], [15]. The results of these studies indicate that the PLT index may have a role in the pathogenesis of COVID-19, although there are studies that show different results. PLTs were found to be lower in critically ill patients compared to patients who were survived. However, not all studies assessed PLT counts as a predictor of COVID-19 mortality [11].

Severely ill patients with systemic immune activation and coagulation have reasonable PLT counts and show a significant compensatory PLT production response. Several mechanisms of thrombocytopenia associated with COVID-19 include lower primary PLT production due to the bone marrow cells were destroyed and bone marrow inhibition, PLT clearance by the immune system and PLT consumption increase by microthrombus. Other mechanisms include PLT clearance due to increased endothelial damage, formation of antibodies against PLTs leading to PLT clearance, sequestration by the spleen and suppression of bone marrow or megakaryocytes [11], [14], [15].

Detection of the SARS-CoV-2 virus with NAAT, in addition to COVID-19 cases confirmation, is also considered as the most sensitive examination to detect the SARS-CoV-2 virus and is the gold-standard examination for COVID-19 confirmation [16], [17]. This study aims to determine the relationship between detection of the SARS-CoV-2 virus using the NAAT examination with the PLT index. Detection of the SARS-CoV-2 virus indicates that the amount of virus is adequate to be detected by NAAT examination, while a negative NAAT examination indicates that the amount of virus in the sample is inadequate to be detected or indicates that the patient has passed the infection phase or has never been infected [18]

The results of this study indicate that NAAT-confirmed COVID-19 patients did not show a significant difference with COVID-19 suspects with negative NAAT group and the control group. There were slightly different median values of PLTs counts observed between the three groups and were still in the normal range even though some subjects had thrombocytopenia and thrombocytosis. This indicates that hospitalized COVID-19 patients do not directly affect the PLT count. There may be other mechanisms that cause changes in PLT counts. A meta-analysis study showed that patients with severe COVID-19 had lower PLT counts compared to non-severe patients. COVID-19 patients who died also had lower PLT counts than those who survived. However, not all studies have found that PLT count can be used as a predictor of COVID-19 mortality [13].

MPV values showed a strong relationship with respiratory syncytial virus infection and chronic hepatitis B infection. MPV value in respiratory syncytial virus infection showed a decrease while hepatitis B virus infection showed an increase [19], [20]. MPV values did not show a consistent relationship with other viral infections. In addition, MPV values did not increase in patients with bacterial sepsis in infants [19], [21]. However, another study found higher MPV values in patients with sepsis compared to controls [22]. The effect of COVID-19 on MPV was seen in the study of Güçlü et al., where patients with elevated MPV were found in COVID-19 patients who died both on the $1^{\text {st }}$ day and after 3 days of follow-up [14]. Studies conducted by Liu et al. and Alnor et al. also showed that COVID-19 might affect PCT values. In the study of Liu et al., COVID-19 patients with thrombocytopenia had lower PCT than non-thrombocytopenia patients. Alnor et al. also found that PCT values were lower in COVID-19 patients than non-COVID-19 patients. However, there was no significant difference in PCT value between COVID-19 patients with severe and non-severe symptoms [23], [24].

This study found that the number of PLT, MPV, and PCT values did not differ significantly between the three groups. This finding indicates that the SARSCoV-2 virus did not directly affect the PLT count, MPV and PCT. In general, research on PLTs and their parameters is performed on COVID-19 patients with severe symptoms, critically ill, or dying patients. The PLT index was changed in COVID-19 patients, especially in patients with severe symptoms, critical conditions or those who die [5], [22], [23]. The mechanism that alters changes in PLT parameters has not been fully understood, but several researchers have provided an overview of the pathogenesis of changes in PLT parameters in COVID-19.

The SARS-CoV-2 virus can infect hemopoietic cells and bone marrow stromal cells, inducing inhibition of PLT production. Patients with cytokine storms may develop progenitor cell damage in the bone marrow that interferes with PLT formation, leading 
to thrombocytopenia. COVID-19 also increases antibodies and immune complexes that cause damage to PLT cells due to the immune system. Lung damage also occurs in COVID-19 patients due to viral infection and inflammation. The cell damage activates PLT to form microthrombi, which causes an increase in PLT consumption resulting in thrombocytopenia [25]. Although the presence of the SARS-CoV-2 virus plays a role in the formation of thrombocytopenia, inflammatory factors and immunological responses have a more dominant role, which further induces PLT index parameters.

\section{Conclusions}

There were no significant differences observed in the number of PLT, MPV, and PCT between COVID-19 patients with positive NAAT, COVID-19 suspects with negative NAAT, and non-COVID-19 controls. Therefore, detecting the SARS-CoV-2 virus by NAAT examination in COVID-19 patients has not altered the PLT index changes.

\section{References}

1. Huang C, Wang Y, Li X, Ren L, Zhao J, Hu Y, et al. Clinical features of patients infected with 2019 novel Coronavirus in Wuhan, China. Lancet. 2020;395(10223):497-506. https://doi. org/10.1016/S0140-6736(20)30183-5

PMid:31986264

2. Liao D, Zhou F, Luo L, Xu M, Wang H, Xia J, et al. Haematological characteristics and risk factors in the classification and prognosis evaluation of COVID-19: A retrospective cohort study. Lancet Haematol. 2020;7(9):e671-e8. https://doi.org/10.1016/ S2352-3026(20)30217-9

PMid:32659214

3. Li Q, Cao Y, Chen L, Wu D, Yu J, Wang $\mathrm{H}$, et al. Hematological features of persons with COVID-19. Leukemia. 2020;34(8):2163-72. https://doi.org/10.1038/s41375-020-0910-1 PMid:32528042

4. Harun $\mathrm{H}$, Bahrun $\mathrm{U}$, Darmawaty E. Platelet-lymphocyte ratio (PLR) markers in acute coronary syndrome. Indones J Clin Pathol Med Lab. 2016;23:7-11.

5. van der Meijden PE, Heemskerk JW. Platelet biology and functions: New concepts and clinical perspectives. Nat Rev Cardiol. 2019;16:166-79. https://doi.org/10.1038/ s41569-018-0110-0

PMid:30429532

6. Comer SP, Cullivan S, Szklanna PB, Weiss L, Cullen S, Kelliher S, et al. COVID-19 Induces a Hyperactive Phenotype in Circulating Platelets, medRxiv; 2020. https://doi. org/10.1101/2020.07.24.20156240

7. Manne BK, Denorme F, Middleton EA, Portier I, Rowley JW, Stubben $\mathrm{C}$, et al. Platelet gene expression and function in patients with COVID-19. Blood. 2020;136(11):1317-29. https:// doi.org/10.1182/blood.2020007214

PMid:32573711

8. Yuki K, Fujiogi M, Koutsogiannaki S. COVID-19 pathophysiology: A review. Clin Immunol. 2020;215:108427. https://doi. org/10.1016/j.clim.2020.108427

PMid:32325252

9. Parasher A. COVID-19: Current understanding of its pathophysiology, clinical presentation and treatment. Postgrad Med J. 2021;97(1147):312-20. https://doi.org/10.1136/ postgradmedj-2020-138577

PMid:32978337

10. Kim JK, Jeon JS, Kim JW, Kim GY. Correlation between abnormal platelet count and respiratory viral infection in patients from Cheonan, Korea. J Clin Lab Anal. 2016;30(3):185-9. https://doi.org/10.1002/jcla.21822 PMid:25545354

11. Chabert A, Hamzeh-Cognasse H, Pozzetto B, Cognasse $F$ Schattner M, Gomez RM, et al. Human platelets and their capacity of binding viruses: Meaning and challenges? BMC Immunol. 2015;16:26. https://doi.org/10.1186/s12865-015-0092-1 PMid:25913718

12. Assinger A. Platelets and infection-an emerging role of platelets in viral infection. Front Immunol. 2014;5:649. https://doi. org/10.3389/fimmu.2014.00649

PMid:25566260

13. Wool GD, Miller JL. The impact of COVID-19 disease on platelets and coagulation. Pathobiology. 2021;88(1):15-27. https://doi.org/10.1159/000512007

PMid:33049751

14. Güçlü $E$, Kocayiğit $H$, Okan $H D$, Erkorkmaz $U$, Yürümez $Y$, Yaylacı S, et al. Effect of COVID-19 on platelet count and its indices. Rev Assoc Med Bras (1992). 2020;66(8):1122-7. https:// doi.org/10.1590/1806-9282.66.8.1122 PMid:32935808

15. Gumus H, Demir A, Yükkaldıran A. Is mean platelet volume a predictive marker for the diagnosis of COVID-19 in children? Int J Clin Pract. 2021;75(4):e13892. https://doi.org/10.1111/ijcp.13892 PMid:3328021

16. CDC. COVID-19 Resources and Guidelines for Labs and Laboratory Workers. Atlanta, Georgia, United States: Centers for Disease Control and Prevention; 2020. Available form: https://www.cdc.gov/coronavirus/2019-ncov/lab/naats.html [Last accessed on 2021 Sep 10].

17. Wang H, Li G, Zhao J, Li Y, Ai Y. An overview of nucleic acid testing for the novel coronavirus SARS-CoV-2. Front Med (Lausanne). 2020;7:571709. https://doi.org/10.3389/fmed.2020.571709 PMid:33537322

18. Pan American Health Organization. Interpretation of Laboratory Results for COVID-19 Diagnosis. Washington, DC, United States: Pan American Health Organization; 2020.

19. Renshaw AA, Drago B, Toraya N, Gould EW.Respiratory syncytial virus infection is strongly correlated with decreased mean platelet volume. Int J Infect Dis. 2013;17(9):e678-80. https://doi.org/10.1016/j.ijid.2013.01.012 PMid:23485431

20. Hu Y, Lou Y, Chen Y, Mao W. Evaluation of mean platelet volume in patients with hepatitis B Virus infection. Int J Clin Exp Med. 2014;7(11):4207-13. PMid:25550932

21. Aksoy HT, Eras Z, Guzoglu N, Canpolat FE, Dilmen U. Mean platelet volume is not associated with bacterial sepsis in newborns. Int J Infect Dis. 2013;17(12):e1263. https://doi. org/10.1016/j.jijid.2013.05.010

PMid:23856507 
22. Guclu E, Durmaz Y, Karabay O. Effect of severe sepsis on platelet count and their indices. Afr Health Sci. 2013;13(2):333-8. https://doi.org/10.4314/ahs.v13i2.19

PMid:24235932

23. Alnor A, Sandberg MB, Toftanes BE, Vinholt PJ. Platelet parameters and leukocyte morphology is altered in COVID-19 patients compared to non-COVID-19 patients with similar symptomatology. Scand J Clin Lab Invest. 2021;81(3):213-7. https://doi.org/10.1080/00365513.2021.1894 601

Author Query???

AQ3: Kindly provide author ORCID

\section{PMid:33685285}

24. Liu Y, Sun W, Guo Y, Chen L, Zhang L, Zhao S, et al. Association between platelet parameters and mortality in coronavirus disease 2019: Retrospective cohort study. Platelets. 2020;31(4):490-6. https://doi.org/10.1080/09537104.2020.1754383 PMid:32297540

25. Xu P, Zhou Q, Xu J. Mechanism of thrombocytopenia in COVID-19 patients. Ann Hematol. 2020;99(6):1205-8. https:// doi.org/10.1007/s00277-020-04019-0

PMid:32296910 